\title{
DIREITO FUNDAMENTAL À PROVA E ÔNUS DAS PARTES: ASPECTOS CONSTITUCIONAIS E IMPLICAÇÕES A PARTIR DO CPC/2015
}

\author{
Jaime Domingues Brito* \\ Paolo Roberto de Angelis Bianco** \\ Victória Santos Marques***
}

Resumo: $\mathrm{O}$ artigo objetiva analisar o direito fundamental à prova e o ônus da sua produção pelas partes, como forma de assegurar a garantia constitucional da tutela jurisdicional adequada e efetiva, a partir de um enfoque na distribuição estática e dinâmica do ônus probatório, da sua inversão e da cooperação processual no $\mathrm{CPC} / 2015$. Através do método dedutivo, baseado em investigações bibliográficas, constatou-se que a distribuição dinâmica do ônus probatório possibilita a universalização das garantias fundamentais do acesso à justiça, do contraditório e da ampla defesa. A pesquisa contribui nas áreas do Direito Constitucional, Direitos Humanos e Fundamentais e Direito Processual Civil.

Palavras-chave: ônus probatório; inversão do ônus; distribuição dinâmica; cooperação processual; tutela jurisdicional.

\section{FUNDAMENTAL RIGHT TO PROOF AND BURDEN OF THE PARTS: CONSTITUTIONAL ASPECTS AND IMPLICATIONS FROM CPC/2015}

\begin{abstract}
The article aims to analyze the fundamental right to proof and the burden of its production by the parts, as a way to ensure the constitutional guarantee of adequate and effective judicial protection, based on static and dynamic distribution of the probative burden, its inversion and procedural cooperation in CPC/2015. Through the deductive method, based on bibliographic investigations, it was found that the dynamic distribution of the evidential burden allows the universalization of fundamental guarantees of access to justice, the contradictory and the broad defense. The research contributes in Constitutional Law, Human and Fundamental Rights and Civil Procedural Law.
\end{abstract}

\footnotetext{
* Advogado. Doutor em Sistema Constitucional de Garantia de Direitos, pela Instituição Toledo de Ensino (ITE). Professor titular na Graduação, Mestrado e Doutorado na Universidade Estadual do Norte do Paraná (UENP). Leciona no Curso de Pós-graduação de Direito Civil e de Processual Civil do Instituto de Direito Constitucional e Cidadania (IDCC), de Londrina/PR. Pesquisador com ênfase nas áreas de Direito Constitucional, Direito Civil, Direito Processual Civil, Bioética e Biodireito. Coordena na UENP o Grupo de Pesquisa Direitos fundamentais e a sistematização precedentalista no Brasil. E-mail: jaimedbrito@hotmail.com; jaimebrito.adv@uol.com.br.

** Advogado. Mestrando em Ciência Jurídica na linha de pesquisa Função Política do Direito pela Universidade Estadual do Norte do Paraná (UENP). Graduado em Direito pela Universidade Estadual do Norte do Paraná (UENP). Participa do Grupo de Pesquisa Intervenção do Estado na Vida das Pessoas (INTERVEPES). Pesquisador com ênfase nas áreas de Direito Digital, Direito Civil e Direito Processual Civil. E-mail: p_roberto7@outlook.com.

*** Advogada. Mestranda em Ciência Jurídica na linha de pesquisa Função Política do Direito pela Universidade Estadual do Norte do Paraná (UENP). Graduada em Direito pela Universidade Estadual do Norte do Paraná (UENP). Participa do Grupo de Pesquisa Intervenção do Estado na Vida das Pessoas (INTERVEPES). Pesquisadora com ênfase nas áreas de Direito Civil, Direito Processual Civil, Direito Constitucional, Direitos Humanos e Fundamentais e Educação. E-mail: victorias_marques@ hotmail.com.
} 
Keywords: burden of proof; inversion of liens; dynamic distribution; procedural cooperation; judicial protection.

\section{INTRODUÇÃO}

Sabe-se que a arcaica divisão entre verdade formal e material não mais se justifica. Atualmente o processo, seja ele penal ou civil, deve buscar a verdade sobre as alegações deduzidas pelo autor e réu, para que ao final o conflito seja solucionado de forma justa, conforme os preceitos e garantias constitucionais, concedendo-se uma prestação jurisdicional adequada às partes.

De fato, as provas judiciais constituem instrumento apto a reconstruir os fatos jurídicos, por serem um conjunto de meios, atividades e resultados que tem como finalidade apurar a veracidade das alegações formuladas nos autos. Dentro do processo, as provas auxiliam na formação da convicção do juiz, na medida em que reconstroem os fatos relevantes para a resolução da lide. Nota-se, pois, que a prova, dentro do processo, constitui verdadeiro direito fundamental, corolário do devido processo legal, do contraditório e da ampla defesa.

No entanto, tratar sobre o direito probatório não é algo simples, posto que caracteriza uma garantia da ciência processual que sempre se modifica, na tentativa de contribuir na efetivação dos preceitos constitucionais.

Com a entrada em vigor do Código de Processo Civil de 2015, o debate quanto ao direito probatório ganhou nova roupagem. É cediço que as partes, com a promulgação do referido diploma legal, assumiram especial relevância, o que, na instrução processual, pode se dar através da produção de provas.

Dentre as principais inovações trazidas pelo CPC/2015 no que diz respeito à prova, pode-se citar a da implementação da teoria da distribuição dinâmica do ônus da prova (art. $373, \S 1^{\circ}$ ), que relativizou a distribuição estática anteriormente existente no CPC de 1973, ao estabelecer que as provas devem atender às especificidades de cada caso, para que se alcance a mais adequada reconstrução dos fatos e, consequentemente, decisões cada vez mais justas.

O que o presente artigo almeja, pois, é verificar se, com a mudança na forma de se encarar a distribuição do ônus da prova no processo, as garantias fundamentais das partes vêm sendo devidamente observadas, e se o processo civil, no âmbito probatório, está sendo 
interpretado e aplicado de acordo com os valores e as normas fundamentais estabelecidas na Constituição Federal.

Com relação à abordagem do tema, o artigo foi dividido em três partes. A primeira delas trata de uma explanação, bem resumida, sobre o surgimento e desenvolvimento de um processo civil pautado nos preceitos constitucionais, na busca da efetivação do Estado Democrático de Direito, ao aspirar a uma tutela jurisdicional adequada. A segunda parte do artigo discorre sobre o direito fundamental à prova e sobre a problemática da distribuição do ônus da prova no CPC de 1973, que adotava a teoria estática.

A terceira e última parte do artigo, por sua vez, dispõe sobre os instrumentos de inversão do ônus da prova, previsto desde o Código Consumerista de 1980, e da distribuição dinâmica do ônus da prova trazida pelo CPC/2015, como mecanismos para a busca da verdade real e de uma justiça cada vez mais efetiva. $\mathrm{O}$ artigo conclui que a opção do atual CPC em adotar o sistema dinâmico de distribuição do ônus da prova (ao invés do estático, anteriormente trazido pelo CPC/1973), almeja atender à finalidade social da jurisdição, ao conferir isonomia material aos polos litigantes e estimular a cooperação processual, tornando o processo mais participativo e democrático, para que haja a resolução do conflito da maneira mais eficiente possível, respeitando-se os preceitos constitucionais.

O método científico utilizado para a elaboração do presente artigo foi o dedutivo, através de uma explanação documental, com levantamento de dados e análise de sua significância, a partir de pesquisas bibliográficas, leitura de obras doutrinárias, outros artigos científicos, revistas jurídicas, e demais textos e materiais, incluída a análise de leis federais, como o Código de Defesa do Consumidor. A pesquisa, pois, enquadra-se nas áreas de Direito Constitucional, Direitos Humanos e Fundamentais e Direito Processual Civil.

\section{O PROCESSO CIVIL CONSTITUCIONAL COMO INSTRUMENTO DO ESTADO DEMOCRÁTICO DE DIREITO E A GARANTIA À TUTELA JURISDICIONAL ADEQUADA E EFETIVA}

A Constituição Brasileira traz, no admirável rol de direitos e deveres individuais e coletivos (art. $5^{\circ}$ ), dentre outras, as garantias da inafastabilidade da jurisdição (inc. XXXV), do juiz natural (inc. LIII), do devido processo legal (inc. LIV), do contraditório e ampla 
defesa (inc. LV), da inadmissibilidade das provas ilícitas (inc. LVI) e da razoável duração do processo e celeridade (LXXVII), com vistas a assegurar que o processo seja um instrumento não apenas regido por um conjunto de normas procedimentais reunidas em torno de um código, mas também calcado na redação da Lei Maior, que abraça esses direitos na qualidade de cláusulas pétreas, proibindo o retrocesso em se tratando de matéria de direitos fundamentais (art. 60, $\S 4^{\circ}$, inc. IV) (BRASIL, 1988, online).

O Código de Processo Civil vigente, por sua vez, replicou preceitos constitucionais ao longo de sua redação, preocupando-se, por exemplo, com o contraditório (art. $9^{\circ}$ e 10), o acesso à justiça (art. $3^{\circ}$ ), a solução integral do mérito em razoável período de tempo (art. $4^{\circ}$ ). Logo no primeiro artigo, enuncia que o processo civil deve ser balizado de acordo com os valores e normas da CF/88 (BRASIL, 2015, online). A reciprocidade de fundamentos processuais na Carta Magna e de diretrizes constitucionais no CPC dá azo ao que Cintra, Grinover e Dinamarco denominam "direito processual constitucional”, isto é, uma colocação sistemática e metodológica acerca dos princípios constitucionais do processo, visualizado tanto sob o enfoque da jurisdição constitucional (controle de constitucionalidade) quanto da tutela constitucional dos princípios relacionados à jurisdição, sua competência e garantias (2014, p. 98).

Não obstante, há que levar em consideração o estatuído no art. $7^{\circ}$ do $\mathrm{CPC}$, consubstanciando a garantia da igualdade substancial às partes no processo, ou seja, a "paridade de tratamento em relação ao exercício de direitos e faculdades processuais, aos meios de defesa, aos ônus, aos deveres e à aplicação de sanções processuais, competindo ao juiz zelar pelo efetivo contraditório" (BRASIL, 2015, online). Deve o juiz, no processo civil constitucional, amparado pelo caput do art. $5^{\circ}, \mathrm{CF} / 88$ e pelo art. 139, inc. I, CPC, assegurar aos sujeitos da demanda igualdade de tratamento, no mais amplo sentido, panorama este que ganha forma com a atribuição de paridade de armas aos indivíduos. Nesse ínterim, sobressaise o contraditório na perspectiva passiva, para a qual seria efetivado ante a mera bilateralidade da audiência, bem assim na ativa, perfazendo a consistente participação do interessado na lide, de modo a influenciar na construção intelectual do julgador (OAB/RS, 2015, online).

A paridade de armas, resguardando a igualdade substancial entre os sujeitos da contenda, abarca as oportunidades de manifestação, produção probatória, exigência de deveres e justa distribuição de ônus, tornando-os aptos a exercer direitos, faculdades, cumprir 
sanções processuais, assim também a realizar meios de defesa, zelando o juiz pelo efetivo contraditório, fundado no contraditório constitucional (art. $\left.5^{\circ}, \mathrm{LV}\right)$, e, consequentemente, pela isonomia material entre os integrantes da ação (TARTUCE, 2015, p. 27-28).

Com efeito, a atual sistemática do processo, sob a esfera do princípio do contraditório, torna imprescindível a efetiva participação dos atores processuais, sejam as partes com os seus patronos, sejam eventuais terceiros interessados em determinada lide, sem prejuízo dos auxiliares da justiça e o próprio magistrado, todos contribuindo para a instalação de um meio igualitário, em que seja possível não apenas o exercício do contraditório, mas também a concretização de uma democracia processual. Asseveram Freitas e Campos que "[...] no processo constitucionalizado as partes se tornam sujeitos processuais ativos na construção da decisão, num contexto processual de atenção às garantias constitucionais e de efetiva participação" (2016, p. 306).

A Constituição e o CPC viabilizam um modelo de processo que foge da tradicional hierarquia triangular e do protagonismo judiciário, à medida que, havendo zelo pelo efetivo e pleno contraditório, prepara os profissionais do Direito para um processo civil comparticipativo e mais humano, no intuito de que seja possível aferir a melhor alternativa para o arremate da questão discutida. Afinal, não se pode olvidar da expressão do art. $8^{\circ}$ do CPC, segundo a qual: “[...] o juiz atenderá aos fins sociais e às exigências do bem comum, resguardando e promovendo a dignidade da pessoa humana e observando a proporcionalidade, a razoabilidade, a legalidade, a publicidade e a eficiência" (BRASIL, 2015, online).

Nesse diapasão, a visão do processo pelo prisma da democracia e do maior envolvimento dos sujeitos se compatibiliza com o Estado Democrático de Direito (art. $1^{\circ}$, caput, CF/88), que "incentiva essa construção conjunta do provimento, de modo a efetivar a participação popular no exercício da função jurisdicional”, cuja legitimidade pressupõe, ao lado da participação das partes, "os aspectos sociais, econômicos e políticos que influenciam o acesso à justiça" (SILVA; NEVES, 2017, p. 100).

O processo civil democrático, pois, é desenvolvido "em consonância com seus mais diversos sujeitos, os quais integram e representam a sociedade, atendendo a diferentes demandas, que podem ser coletivas ou individuais, com o intuito de buscar a ordem jurídica justa". Assim, a Constituição e o processo, em harmonia, preservam os valores democráticos 
da República, a partir da efetividade das garantias processuais, do fomento participativo do juiz e das partes e da observância do juiz natural, do duplo grau de jurisdição e do contraditório, "responsáveis pela maturidade na ciência processual contemporânea" (SILVA; NEVES, 2017, p. 101). Nesse sentido,

[...], os direitos fundamentais só podem ser exercidos em contextos democráticos, ao mesmo tempo em que são essenciais para a existência da própria democracia. [...] É de se reconhecer que, do ponto de vista normativo, a democracia contemporânea demarca o contexto amplo das garantias institucionais no qual é possível a ocorrência dos direitos fundamentais, constituindo-se, ela própria, um direito fundamental (ALVES, 2014, p. 37, 38).

Freitas e Campos (2016, p. 306) debatem que o princípio democrático, na seara jurisdicional, dará origem ao dever estatal e ao direito do jurisdicionado de procurar solucionar "suas pretensões, com a devida fundamentação, mediante a garantia de ampla participação na construção das decisões, observado, assim, o devido processo constitucional, aqui entendido como a devida aplicação da constituição". Logo, para a pessoa que busca o Judiciário, pleiteando determinado direito ou pedindo a guarida de um bem jurídico que está sendo violado, surge o direito correspondente à obtenção de uma tutela jurisdicional célere, justa e efetiva, corporificado em uma das facetas do princípio da inafastabilidade da jurisdição, consoante ensinamento de Dori e Cambi (2018, p. 50-51):

\begin{abstract}
A garantia da inafastabilidade da tutela jurisdicional possui duplo aspecto: a relação entre a jurisdição e a solução administrativa de conflitos; e o acesso à ordem jurídica justa. A conjugação desses dois aspectos resulta que a inafastabilidade somente existirá concretamente quando o direito processual tutela os interesses da parte titular do direito material. [...] O termo "acesso à justiça" indica duas finalidades do sistema jurídico: o sistema por meio do qual os indivíduos podem reivindicar seus direitos, resolver litígios sob a proteção do Estado, que deve ser acessível a todos; e que o Estado deve possibilitar resultados individual e socialmente justos.
\end{abstract}

A aspiração a uma tutela jurisdicional célere, adequada e efetiva, que viabilize um processo que não seja somente estático, analisado do ponto de vista formal, mas também compreendido como um instrumento mínimo, apto a gerar meios e resultados, coaduna-se com a perspectiva constitucional dos direitos fundamentais, vinculando o legislador a limitar a 
própria atuação, bem assim a regulamentar dispositivos da Carta Magna com vistas a assegurar de forma eficiente a proteção judiciária (CAMBI, 2020, p. 302-304).

Nesta senda, coligindo o movimento de constitucionalização do processo civil juntamente ao dever do Estado-Juiz de salvaguarda das garantias constitucionais, a exemplo do devido processo legal, da duração razoável do processo, da ampla defesa e do contraditório substancial, e, ainda, analisando essa sistemática pelo prisma do Estado Democrático de Direito, torna-se possível a afirmação de que o CPC/2015 visou à instauração de um paradigma processual comparticipativo e policêntrico, democratizando a dialética da contenda, voltando a efetividade do procedimento para o esforço comum dos sujeitos participantes da lide e incentivando a construção conjunta do provimento pretendido.

Enfim, é imperioso destacar que a relação do contraditório com o processo constitucional, fundamentada na igualdade de tratamento despendida às partes, faz aparecer, em meio a outros fatores, a necessidade de se estudar o instituto da prova no processo civil como mecanismo de materialização dos princípios processuais constitucionais, haja vista o encorajamento da participação popular e a oportunidade de se exercer plenamente o contraditório, "consistente no dizer, contradizer ou se abster de dizer quando o fato constitutivo do direito tiver que ser produzido pela parte contrária”. Sendo uma forma de assegurar o contraditório, o direito à produção de provas é interpretado como "garantia efetiva de influência nos pronunciamentos judiciais, consistente na possibilidade de dizer e contradizer em um inter-procedimental marcado pela paridade de partes", sendo o seu óbice uma "ofensa às garantias constitucionalmente positivadas" (DIAS, 2016, p. 518-519, 521).

Isso porque a prova "constitui-se em instituto essencial para a realização do Estado Democrático de Direito, sendo fator indispensável à composição da ideia de um processo justo, impedindo, em face de sua essência, a tomada de decisões arbitrárias" (REICHELT; PORTO, 2017, p. 304). Sem dúvida, para que se realize o modelo de processo colaborativo, o julgador, como já se disse, deve ser "isonômico na sua condução e assimétrico apenas quando impõe suas decisões", ou seja, paritário no diálogo e assimétrico no pronunciamento. A cooperação pressupõe o equilíbrio de posições jurídicas dos participantes e intenciona "servir de elemento para organização de processo justo idôneo a alcançar decisão justa" (MITIDIERO, 2012, p. 71). 
Em virtude dessas considerações iniciais, tem-se que a garantia do acesso à justiça representa não somente a provocação do Poder Judiciário com a propositura de uma ação, mas também a esperança de que a tutela do direito do jurisdicionado será célere, pertinente e efetiva, isto é, que se está pleiteando a aplicação do ordenamento jurídico de forma justa, tendo em vista a base principiológico-garantista assegurada pela Lei Maior, a qual deverá incidir em todos os conflitos, sejam eles de menor ou maior complexidade, de ordem cível ou penal, no âmbito da Justiça Estadual ou Federal, comum ou especializada. O processo constitucional, em especial o processo civil, que aqui se estuda, consolida a fundamentalidade de a interpretação normativa se pautar nos valores e garantias fundamentais exarados na Constituição, a fim de que haja maior efetividade ao provimento pretendido, sem prejuízo da execução de um paradigma cooperativo e participativo entre os atores processuais, com fulcro no direito ao contraditório substancial, na ampla defesa, na duração razoável do processo, no devido processo legal e na dignidade humana, traduzida como um dos pilares do Estado Democrático de Direito.

Nessa esteira, será assinalada a situação do direito fundamental à prova no ordenamento pátrio, bem assim a distribuição de seu ônus e as incumbências a ele atreladas, quer no CPC anterior, quer no vigente. Averiguando-se a questão da produção de provas como natural consectária do contraditório, serão estudados os institutos da inversão do ônus probatório e de sua distribuição dinâmica à luz do princípio da cooperação processual.

\section{O DIREITO FUNDAMENTAL À PROVA E A PROBLEMÁtica do ÔNUS ATRIBUÍDO Às PARTES NO CPC/1973}

A partir da Constituição Federal de 1988, foi elencada uma gama de direitos fundamentais (compreendidos os direitos individuais, sociais, políticos e jurídicos), que devem ser assegurados a todos os cidadãos, por serem a eles inerentes, constituindo verdadeiros fundamentos do ordenamento jurídico, por criarem pressupostos básicos ligados à dignidade da pessoa humana.

De acordo com Ingo Sarlet, os direitos fundamentais são aqueles direitos do homem reconhecidos e positivados em um determinado ordenamento jurídico, ao passo que os direitos humanos guardam relação com os documentos internacionais, independentemente de 
sua vinculação com determinada ordem constitucional, tendo, portanto, uma validade universal, para todos os povos e tempos, revelando um caráter supranacional (2013, p. 389).

De fato, a evolução da humanidade passou a exigir uma nova concepção de efetividade dos direitos fundamentais, colocando-os num grau mais alto de juridicidade, concretude, positividade e eficácia. A CF/88, além de positivar expressamente os direitos fundamentais de primeira, segunda e terceira gerações/dimensões, permite a existência de direitos fundamentais implícitos $\left(\operatorname{art} .5^{\circ}, \S 2^{\circ}\right.$ ), o que demonstra que seu rol não é taxativo. Em seu art. $5^{\circ}, \S 1^{\circ}$, dispôs acerca da aplicabilidade imediata das normas definidoras dos direitos fundamentais.

Entre os direitos fundamentais implícitos na $\mathrm{CF} / 88$, pode-se citar o direito à prova. $\mathrm{A}$ prova é o meio para inserir no processo os fatos ocorridos, ou seja, para demonstrar que os fatos efetivamente ocorreram conforme narrados pela parte, de modo que se forme a convicção do juiz para que o caso concreto possa ser solucionado, com uma justa decisão.

Conforme Eduardo Cambi, o termo prova é plurissignificante, podendo ser conceituado como meio, atividade e resultado. É meio, por ser instrumento colocado à disposição das partes para comprovar a veracidade de suas alegações. É atividade, pois submetida a um procedimento que disciplina sua admissibilidade, produção e valoração. E é resultado, porque sua realização objetiva a formação do convencimento judicial (2014, p. 21).

Com efeito, a produção da prova pode se dar de diversas formas, através da oitiva de testemunhas, perícias, depoimento das partes, juntada de documentos, etc. Na verdade, não há limitações quanto aos meios de prova, desde que a prova seja lícita e idônea.

Quanto ao direito à prova como um direito fundamental, este não possui a merecida atenção doutrinária, não sendo estudado separadamente, mas normalmente inserido em outros direitos constitucionais (CANOTILHO, 2008, p. 169-170). Nem a CF/88 nem a lei afirmam esse direito de modo amplo e direto, não existindo garantia constitucional específica do direito à prova, podendo ser extraído de uma amplitude mais geral (DINAMARCO, 2005, p. 47-48).

Entre os princípios constitucionais fundamentadores do direito à prova, pode-se citar o princípio da inafastabilidade da jurisdição ou do direito de ação, que permite o acesso à justiça (art. $5^{\circ}, \mathrm{XXXV}$ ), o princípio do devido processo legal (art. $5^{\circ}$, LIV), o princípio do 
contraditório e da ampla defesa (art. $\left.5^{\circ}, \mathrm{LV}\right)$, o princípio da isonomia (art. $5^{\circ}$, caput), entre outros.

Quanto aos tratados internacionais ratificados pelo Brasil, o direito à prova é assegurado pelo Pacto de São José da Costa Rica, pelo Pacto Internacional de Direitos Civis e Políticos, pela Convenção Europeia dos Direitos do Homem e pela Declaração de Direitos e Liberdades Fundamentais. Referidos documentos, incorporados ao ordenamento jurídico interno, integram o rol dos direitos fundamentais, o que reafirma ser o direito à prova um direito fundamental (PADILHA, 2016, online).

Quanto ao destinatário da prova, este é diretamente o juiz, conforme se infere do art. 371, do CPC. No entanto, muitos estudiosos entendem que as partes e os demais interessados também são seus destinatários, por possibilitar que demonstrem os fatos alegados.

De fato, com relação à valoração da prova, o art. 371, do CPC adotou o sistema da persuasão racional. Como dito, o juiz deve fundamentar suas decisões com base nos elementos constantes nos autos e motivar a escolha pelos elementos formadores de convicção apresentados pelas partes. Por exemplo, ao juiz cabe dar à confissão (que é um meio de prova), o valor segundo seu poder de convencimento, em consonância com as demais provas produzidas.

Sabe-se que os poderes de um juiz, dentro do processo, devem ser limitados, sob pena de haver uma decisão ilegítima e injusta. Além disso, para que haja uma correta decisão, esta não deve ser centrada unicamente na figura do magistrado: deve haver a participação das partes, que tem de provar os fatos que embasam as suas alegações. Tal exercício, além de ser um direito fundamental, é também um ônus.

O ônus consiste na atribuição de determinada incumbência a um sujeito no interesse desse próprio sujeito. Ou seja, prescreve-se ao onerado uma conduta a adotar, pela qual ele poderá obter uma vantagem ou impedir uma situação que lhe seja desfavorável. Ônus e dever são figuras jurídicas distintas em pelo menos dois aspectos: (i) o dever implica um correlato direito de outro sujeito, ou seja, é uma conduta que a lei prescreve no interesse de outrem, enquanto que o ônus é estabelecido no interesse do próprio onerado; (ii) o descumprimento do dever pode implicar a incidência de uma sanção, ao passo que a inobservância do ônus apenas faz com que o onerado eventualmente perca a chance de desfrutar de uma situação melhor (TALAMINI, 2016, online). 
De fato, conceitualmente, o ônus da prova é a atribuição, à parte, da incumbência de comprovar fatos que lhe são favoráveis no processo, caso as provas constantes nos autos não sejam suficientes para tanto. Ou seja, o ônus da prova é imprescindível quando não há provas de determinado fato nos autos. Se existem essas provas no processo independentemente de quem a produziu, competindo ao juiz reconhecer os efeitos que ela produz, adequando os fatos às normas jurídicas pertinentes - as regras do ônus da prova são desnecessárias (TALAMINI, 2016, online).

Como dito, se não há prova nos autos, deve ser aplicado o instituto do ônus da prova para que o magistrado possa solucionar a demanda e aplicar o direito. Isso porque o processo não pode durar indefinidamente em busca da verdade dos fatos. É preciso que haja a rápida conclusão da lide, sob pena de grave afronta ao direito fundamental à razoável duração do processo, às garantias da celeridade e efetividade. Por outro lado, o juiz não pode deixar de decidir sob o argumento de que não conseguiu formar convencimento sobre os fatos da causa (vedação ao non liquet). E é para essas situações em que o magistrado ainda não formou o seu convencimento que a lei fixa as regras sobre distribuição do ônus da prova (TALAMINI, 2016, online).

\begin{abstract}
[...] mediante a distribuição do ônus da prova, estabelecem-se regras destinadas a nortear a atividade do julgador e sistematiza-se o procedimento probatório, evitando-se diligências desnecessárias e indesejáveis. Então, as normas sobre ônus probatório, por um lado, são "regras de julgamento", isso é, são dirigidas ao julgador, no momento de sentenciar. Por outro, fornecem parâmetros para as partes previamente estabelecerem sua estratégia probatória: autor e réu primeiramente se concentrarão em provar os fatos sobre os quais recaem os seus respectivos ônus da prova (TALAMINI, 2016, online).
\end{abstract}

Disso decorre que a regra do ônus da prova é de aplicação subsidiária, cabível somente em caso de subsistir algum fato controvertido ao final da instrução que careça de prova. Em síntese, tem-se que o ônus da prova é um sucedâneo da prova faltante (RAMOS, 2015, online).

No mais, sabe-se que o ônus da prova pode ser analisado sob o aspecto subjetivo e o objetivo. Subjetivamente, o ônus representa uma regra de conduta dirigida às partes, cabendo a cada uma delas provar as alegações que formulou, para tentar convencer o juiz da sua veracidade. Objetivamente, as regras do ônus da prova são dirigidas ao juiz, para orientar o 
seu julgamento. Na doutrina, predomina o entendimento de que o ônus da prova é, essencialmente, regra de julgamento e não de atividade (RAMOS, 2015, online).

Quanto à distribuição do ônus da prova entre as partes, o CPC de 1973 adotou a teoria estática, levando em consideração a posição das partes, o interesse no fato a ser provado e a natureza dos fatos (constitutivos, impeditivos, modificativos ou extintivos). Não havia uma preocupação com as peculiaridades do direito material a ser tutelado, nem as circunstâncias do caso concreto. O CPC de 1973 estava pautado na concepção liberal individualista para resolver a lide, o que era incompatível com a promoção de um processo coletivo e efetivamente democrático (CAMBI, 2020, p. 454-455).

O art. 333 do CPC-1973 distribuía o ônus da prova, sem levar em consideração o direito fundamental à tutela jurisdicional adequada e efetiva (art. $5^{\circ}, \mathrm{XXV}$, $\mathrm{CF} / 1988$ ), além de partir da premissa de que ambos os litigantes estariam, formalmente, em paridade de armas e, por isto, tinham iguais condições de produzir a prova. [...] a regra do art. 333 do CPC-1973 era materialmente incompatível com a produção da prova nos processos coletivos, porque colocava em risco a efetividade da tutela do direito material coletivo (CAMBI, 2020, p. 455).

Esse panorama, contudo, foi alterado pelo Código de Defesa do Consumidor (art. $6^{\circ}$, VIII, CDC), bem como pelo Código de Processo Civil de 2015 (art. 373, § 1º ), o que acabou por gerar a superação do modelo liberal-patrimonialista do CPC de 1973. Houve, em verdade, o surgimento da cooperação processual na distribuição do ônus da prova, que se tornou dinâmico, o que passa a ser explicado a seguir.

\section{COOPERAÇÃO PROCESSUAL SOB A ÉGIDE DA INVERSÃO E DISTRIBUIÇÃO DINÂMICA DO ÔNUS DA PROVA: UMA ANÁLISE DO CDC E DO CPC/2015}

A democracia, entendida por Alves (2014, p. 28) como "uma construção cultural que resulta da interação de diversos fatores sociais, políticos, jurídicos e econômicos”, assenta-se na lei processual infraconstitucional, influenciando sua interpretação, ordenamento e disciplina. Além disto, consoante o retro explanado, convida os sujeitos integrantes da lide a cooperarem, participarem das discussões de forma construtiva, no mesmo plano de igualdade, no intuito de obterem prestação jurisdicional considerada rápida e efetiva por todas as partes. 
A relação entre os âmbitos processual e constitucional, relativamente à esfera cível, deu origem ao Processo Civil Democrático, o qual se constrói de forma dialógica, coparticipativa, policêntrica, não mais centrado na pessoa do juiz, mas conduzido por todos os sujeitos do processo, todos eles igualmente importantes em sua construção (CÂMARA, 2015). Isso se reafirma no art. $6^{\circ}$ do NCPC, que dispõe: "todos os sujeitos do processo devem cooperar entre si para que se obtenha, em tempo razoável, decisão de mérito justa e efetiva" (SILVA; NEVES, 2017, p. 99$100)$.

A redação do art. $6^{\circ}$ do $\mathrm{CPC}$, como se vê, corrobora a ideia de o processo civil pressupor a ativa participação de todas as partes e demais sujeitos de forma igualitária, unindo esforços para que a prestação jurisdicional seja célere, adequada, efetiva e, preferencialmente, de mérito, de forma que a incidência maior dessa interação intersubjetiva terá lugar no momento processual de produção de provas. Mitidiero (2012, p. 71-72, grifos do autor) leciona que o julgador "tem os deveres de esclarecimento, de diálogo, de prevenção e de auxílio para com os litigantes. É assim que funciona a cooperação. Esses deveres consubstanciam as regras que estão sendo enunciadas quando se fala em colaboração no processo".

Frise-se, consequentemente, que a atividade probatória objetiva o convencimento das partes e também do magistrado, cuja preocupação recai sobre a descoberta da verdade real, sem prejuízo de se poder "construir uma decisão justa, haja vista que na civil law o processo é de interesse público e a atividade jurisdicional representa o Estado" (SILVA; NEVES, 2017, p. 104, grifo das autoras).

Quanto à importância do direito à prova, a lição de Cintra, Grinover e Dinamarco $(2014$, p. 405,411$)$ explicita que se trata de "um dos mais respeitados postulados inerentes à garantia política do devido processo legal, a ponto de se constituir em um dos fundamentais pilares do sistema processual contemporâneo", e mais, que "sem sua efetividade não seria efetiva a própria garantia constitucional do direito ao processo", cabendo ao juiz, em função da democratização do processo civil, o poder de iniciativa probatória, limitado a determinadas circunstâncias, a exemplo dos direitos indisponíveis e da hipossuficiência de uma das partes.

Poderá, inclusive, determinar a produção de provas indispensáveis ao julgamento do mérito tanto a requerimento da parte quanto de ofício (art. 370, CPC), haja vista a busca pela verdade real (e não meramente formal), a fim de que eventual decisão seja, de fato, justa. Todavia, "para evitar arbitrariedade, a apreciação das provas realizada pelo juiz é limitada 
pela motivação, de modo que ele atribui à prova, produzida pelas partes, o valor e o grau a partir do seu convencimento", desde que justifique publicamente as razões de sua convicção, de sorte que as partes possam impugná-las pela via recursal (SILVA; NEVES, 2017, p. 109).

Reichelt e Porto (2017, p. 307) atestam que o papel do magistrado, "como verdadeiro defensor do respeito à ordem jurídica, somente é devidamente cumprido na medida em que o seu agir seja capaz de implementar o desenvolvimento de um processo justo". Assim, uma de suas competências principais é a determinação da produção probatória e de outras medidas que reputar necessárias para conduzir efetivamente a atividade instrutória. Em complemento, Cambi (2020, p. 334) sustenta que "a atividade judicial é controlada pelos direitos e garantias fundamentais que compõem o direito ao justo processo (v.g., juiz natural, contraditório, ampla defesa, devido processo legal, vedação de provas ilícitas, dever de motivação das decisões etc.)", assim também que o pronunciamento judicial, exarado dentro do discurso jurídico, legitima-se a partir "da sua força intrínseca de persuasão", devendo "ser capaz de, mediante seus juízos de valor, convencer a comunidade jurídica e a sociedade”.

Surge, na busca pela verdade real, a problemática da distribuição do ônus probatório às partes, o que ocorrerá conforme as particularidades do caso concreto. Dias conceitua o ônus como sendo a "faculdade do sujeito processual em produzir prova favorável ou contrária ao fato substrato da lide, cuja opção pelo não exercício poderá acarretar prejuízo àquele que se desincumbiu de provar". A parte interessada exerce o livre arbítrio de requerer e produzir as provas que considerar relevantes para comprovar suas alegações, colaborando com a edificação do convencimento do julgador. Vale ressaltar, ademais, que o ônus da prova “estará em desacordo com os postulados do processo sob a égide do Estado Democrático de Direito" quando se tornar "impossível ou de extrema dificuldade o exercício da faculdade probatória" (2016, p. 521).

Cumpre examinar, por conseguinte, as disposições legais atinentes ao ônus da prova. O CDC, alicerçado no direito fundamental segundo o qual o Estado deve promover a defesa do consumidor (art. 5, XXXII, CF/88), dispõe, no art. 6º, VIII, que é um direito básico do consumidor "a facilitação da defesa de seus direitos, inclusive com a inversão do ônus da prova, a seu favor, no processo civil, quando, a critério do juiz, for verossímil a alegação ou quando for ele hipossuficiente, conforme as regras ordinárias de experiências" (BRASIL, 1990, online, grifos nossos). 


\begin{abstract}
A verossimilhança significa que as alegações do consumidor devem corresponder a uma situação plausível, com possibilidade de ocorrência a partir das regras da experiência. Por exemplo, seria o caso de imaginar uma hipótese em que o consumidor ingressa em juízo, alegando que contratou o fornecimento de determinado serviço, porém sem o receber. De outro lado, tem-se, também, a hipossuficiência do consumidor, que significa a existência de uma situação de desigualdade entre este e o fornecedor, em desfavor do primeiro. [...] A melhor exegese do artigo $6^{\circ}$, inciso VIII, parece residir na hipossuficiência técnica, isto é, numa situação em que se encontra o consumidor em prejuízo para a análise técnica do bem ou serviço objeto da relação jurídica material, e não na econômica, que revela apenas um maior poder financeiro do fornecedor (RODRIGUES, 2013, p. 548-549).
\end{abstract}

A especificidade de se inverter o ônus probatório, inserida no microssistema de defesa e proteção ao consumidor, justifica-se pela vulnerabilidade deste frente à cadeia de fornecedores, tendo em vista que nem sempre dispõe dos conhecimentos técnicos ou das informações necessárias para realizar a própria prova. Desse modo, para garantir que as partes estejam em condições paritárias de participação e construção dialógica processual, capazes de formar o convencimento do juiz, a inversão, deferida mediante adequada fundamentação in casu, opera no sentido de equilibrar as armas, evitando prejuízo à parte que não está apta a provar o fato constitutivo de seu direito, especialmente quando se constata que o adversário possui melhores condições de provar o fato negativo (DIAS, 2016, p. 522).

Há quem defenda que o instituto passou a ser utilizado de maneira indiscriminada, de tal monta que a distribuição do ônus nas lides consumeristas acarretou, por vezes, ofensa ao contraditório do polo incumbido de comprovar o fato negativo, resultando em decisões desfavoráveis a si. À vista disso, levantou-se o debate se a inversão do ônus consistiria em regra de instrução ou regra de julgamento. A jurisprudência do Superior Tribunal de Justiça, a partir de 2011, filiou-se à tese de que o direito proclamado no art. $6^{\circ}$, VIII do CDC traduz-se numa regra instrutória, "sendo que a decisão que a determinar deve - preferencialmente ocorrer durante o saneamento do processo ou - quando proferida em momento posterior garantir a parte a quem incumbia esse ônus a oportunidade de apresentar suas provas" (DIAS, 2016, p. 523, 524), possibilitando às partes o exercício do contraditório pleno indistintamente.

A seu turno, o art. 373 do CPC exprime que o ônus da prova caberá ao autor, "quanto ao fato constitutivo de seu direito", e ao réu, "quanto à existência de fato impeditivo, modificativo ou extintivo do direito do autor" (incisos I e II). Já o $§ 1^{\circ}$ desse dispositivo aduz 
que o magistrado poderá, em caráter excepcional, "atribuir o ônus da prova de modo diverso, desde que o faça por decisão fundamentada, caso em que deverá dar à parte a oportunidade de se desincumbir do ônus que lhe foi atribuído", o que ocorrerá tanto quando houver "peculiaridades da causa relacionadas à impossibilidade ou à excessiva dificuldade de cumprir o encargo nos termos do caput ou à maior facilidade de obtenção da prova do fato contrário" quanto nas demais hipóteses previstas em lei (BRASIL, 2015, online).

Concebeu o CPC/2015, dessa maneira, a dinamização do ônus probatório, que ainda não havia sido positivada pelo direito brasileiro, mas que ganhava força na doutrina e jurisprudência, ampliando a noção antes exclusiva de CDC de se atribuir carga probandi maior aos que melhor tiverem condições para suportá-la. Premente, pois, a verificação casuística subjetiva e objetiva para, então, motivadamente, o juiz aplicar o instituto, em prestígio à paridade de armas, à isonomia e ao contraditório. Com efeito, sustenta-se que a dinamização da distribuição do ônus preserva também a boa-fé processual, “impedindo comportamentos imorais ou abusivos por aqueles que possuam melhores condições de provar" (RODRIGUES, 2013, p. 555).

Veja-se que, consagrada a teoria da distribuição dinâmica do ônus, o CPC indica, em sequência, essencial critério para a sua aplicação, estatuindo que "não pode gerar situação em que a desincumbência do encargo pela parte seja impossível ou excessivamente difícil" $\left(\$ 2^{\circ}\right)$, e permitindo às partes convencionarem quanto à distribuição diversa do ônus, antes ou durante o processo, a menos que o acordo recaia sobre direito indisponível ou torne o exercício do direito excessivamente difícil a uma delas ( $\left(3^{\circ}\right.$ e $\S^{\circ}$ ) (BRASIL, 2015, online).

Segundo Carvalho (2017, p. 353-355), a regra estática do ônus da prova, sancionada tanto no CPC de 1973 quanto no de 1939, era assim denominada em função de a rígida imposição normativa se debruçar unicamente sobre a posição que cada parte ocupava na disputa e a natureza dos fatos, sem que o juiz levasse em conta a natureza do direito pleiteado ou as condições econômicas e técnicas dos sujeitos. Em consequência, a crítica a essa inflexibilidade era a de que "podia levar a um injusto provimento jurisdicional, afastando, em consequência, a norma processual de sua função constitucional", qual seja, a de "garantir a plena efetividade aos desígnios do direito material e jamais se revelar um óbice à materialização dos valores perfilhados pelo direito substancial". Com o advento da $\mathrm{CF} / 88$, não haveria como prosperar tal convicção, considerados os anseios e a pluralidade social, bem 
como o aparecimento de conflitos das mais diversas naturezas e complexidades. Logo, sem razão a padronização excessivamente rígida do ônus probandi, "um dos mais importantes fatores aptos a influenciarem a formação da cognição processual”.

Ainda no sentir de Carvalho (2017, p. 369), o CPC/2015 “contemplou não apenas o aspecto objetivo do ônus da prova, mas também o subjetivo. Deste modo, o ônus da prova mantém-se como regra de julgamento (aspecto objetivo), e, ainda, serve de estímulo à parte para que produza as provas visando a influenciar convencimento do juiz (aspecto subjetivo)".

Uma vez considerados pela doutrina "a coluna vertebral do processo civil", porquanto cumprem a finalidade precípua do processo de "atingir os desígnios concretos do direito material", o exercício do direito fundamental à prova e a distribuição do ônus influem diretamente na busca pela tutela constitucionalmente justa e desejável (CARVALHO, 2017, p. 355). Por fim, retomando o teor dos artigos $5^{\circ}$ e $6^{\circ}$ do CPC, sublinha-se a importância de os polos processuais contribuírem solidamente para o deslinde e progresso da ação em trâmite, em consonância com a ideal valoração constitucional conferida ao ordenamento instrumental, com atenção especial para o dever atribuído às partes de se comportar com boa-fé, probidade, idoneidade, culminando no primado da cooperação mútua, sem o qual a própria dialeticidade da atividade probatória restaria prejudicada, tal qual o empenho pela obtenção da verdade real.

\section{CONCLUSÃO}

A exegese do direito fundamental à prova sob a ótica do processo civil constitucional deflagra a necessidade de se estabelecer um meio processual democrático e inclusivo, disciplinado consoante os valores da Lei Suprema, asseguradas a apreciação jurisdicional de ameaça ou lesão a direito, a garantia à tutela satisfativa justa e célere, a boa-fé, a cooperação intersubjetiva, a paridade de tratamento e o pleno e efetivo contraditório entre as partes, as exigências do bem comum e fins sociais decorrentes da aplicação do ordenamento, a ampla defesa, a adequada motivação decisória, dentre outros preceitos fundamentais.

As partes são chamadas a dialogar junto com o Estado-Juiz e os atores auxiliares da justiça, construindo um procedimento colaborativo e participativo, no qual floresce significativamente a atividade probatória, corolária do pleno contraditório. Em face desse 
cenário, a pesquisa ponderou qual deve ser o papel do Judiciário na condução do feito, que já se afasta do tradicional paradigma triangular, das partes subordinadas ao juiz, em detrimento do modelo cooperativo, com paridade de armas aos litigantes e, ao julgador, a incumbência de sopesamento dos interesses, esclarecimento, diálogo, prevenção e auxílio, cabendo ainda a si a paridade no diálogo e a assimetria no pronunciamento. Nessa toada, almeja-se obter, em razoável período de tempo, a justa e efetiva decisão de mérito.

No escopo da atividade instrutória, o magistrado faz uma análise do caso concreto e das partes envolvidas na lide, aferindo se os meios de prova escolhidos são capazes de dirigir a discussão para uma resolução. Ao juiz, portanto, cabe a verificação a respeito da suficiência da prova. Sendo ela suficiente, não importa quem a produziu (princípio da comunhão das provas). No caso de insuficiência, contudo, a regra do ônus ganha relevo, pois é a partir da ausência que é determinado quem deve arcar com a falta da prova.

Pelo exposto, vislumbrou-se que o juiz pode, a depender da singularidade de cada questão, atender aos requerimentos das partes ou determinar de ofício a produção de provas, no constante intuito de tornar o processo eficiente. Ainda, pode valer-se da inversão do ônus probandi, seja num conflito consumerista, quando o consumidor comprovar a verossimilhança fática e a hipossuficiência técnica, seja nas demandas cíveis, quando for mais fácil a obtenção de prova do fato contrário, assim também impossível ou de extrema dificuldade o cumprimento do encargo probatório pelo autor ou pelo réu. Neste caso, não se trata de simples inversão, mas da distribuição dinâmica do ônus, que poderá assumir diversas facetas e terá lugar mediante fundamentada decisão judicial, atendendo às imposições casuísticas, com o fito de se buscar a verdade real das alegações.

Consigna-se, ainda, que, com o CPC de 1973, vigorava a teoria da distribuição estática do ônus. É de se verificar que a distribuição dinâmica era considerada uma postura ativista do juiz ante à regra estática do procedimento. Visualiza-se como acertada a mudança para a sistematização hodierna, uma vez que demanda uma postura mais ativa da atuação judicante para enfrentar a celeuma da comprovação dos fatos e alcance da verdade real, o que depende muito também de cada situação que se apresenta, vindicando cada vez mais um comum esforço das partes para demonstrar se possuem condições de suportar o encargo probatório. Ademais, no tocante à inversão do ônus da prova, notou-se que, enquanto parte da 
doutrina ainda entende que o instituto constitua regra de julgamento, a jurisprudência do STJ tem se firmado no sentido de aplicá-la como regra de instrução.

De todo modo, a atividade jurisdicional, conquanto imprescindível para orientar o procedimento e zelar pela produção de provas e pela duração razoável do processo, depara-se com o dever de conferir isonomia material aos polos litigantes, estimulando o contraditório e o raciocínio conjunto em direção a uma solução para o conflito, em deferência ao postulado da cooperação processual, assentado, a seu turno, no bojo da inafastabilidade da jurisdição.

No mais, afigura-se relevante a análise da sistemática processual civil contemporânea, centrada no preceito democrático e na compatibilidade de suas regras com a Constituição da República. Assim sendo, o processo serve como instrumento de consolidação e efetivação dos valores fundamentais, objetivando não apenas um provimento justo e satisfativo, mas, outrossim, atender à finalidade social da jurisdição, qual seja, a pacificação dos conflitos. Nesse meio, o instituto da prova assegura a efetiva participação das figuras do processo no debate que se trava, concretizando o contraditório, respeitando a ampla defesa, realizando a isonomia material e desenvolvendo a cooperação inter partes.

\section{REFERÊNCIAS}

ALVES, Fernando de Brito. Democracia à portuguesa: retórica democrática na tradição jurídica lusófona. Rio de Janeiro: Lumen Juris, 2014.

BRASIL. Lei n 5.869 , de 11 de janeiro de 1973. Institui o Código de Processo Civil. Disponível em: <http://www.planalto.gov.br/ccivil_03/leis/15869impressao.htm>. Acesso em: 09 set. 2020.

Constituição da República Federativa do Brasil. Brasília, DF: Senado Federal, 1988. Disponível em: <http://www.planalto.gov.br/ccivil_03/constituicao/constituicao.htm>. Acesso em: 09 set. 2020.

Lei $n^{\circ}$ 8.078, de 11 de setembro de 1990. Código de Defesa do Consumidor.Dispõe sobre a proteção do consumidor e dá outras providências. Disponível em: <http://www.planalto.gov.br/ccivil_03/leis/18078compilado.htm>. Acesso em: 10 set. 2020.

Lei no 13.105, de 16 de março de 2015. Código de Processo Civil. Disponível em: <http://www.planalto.gov.br/ccivil_03/_ato2015-2018/2015/lei/113105.htm>. Acesso em: 09 set. 2020.

CAMBI, Eduardo. Curso de direito probatório. 22ª ed. Curitiba: Juruá, 2014. 
Neoconstitucionalismo e Neoprocessualismo: direitos fundamentais, políticas públicas e protagonismo judiciário. $3^{\mathrm{a}}$ ed. Belo Horizonte, São Paulo: D'Plácido, 2020.

CANOTILHO, Joaquim José Gomes. Estudos sobre direitos fundamentais. São Paulo: RT, 2008.

CARVALHO, Sabrina Nasser de. Premissas para a melhor compreensão da dinamização do ônus da prova no novo CPC. Revista Eletrônica de Direito Processual - REDP. Rio de Janeiro. Ano 11. Volume 18. Número 1. Janeiro a Abril de 2017. Periódico Quadrimestral da Pós-Graduação Stricto Sensu em Direito Processual da UERJ. ISSN 1982-7636, p. 346-376.

CINTRA, Antonio Carlos de Araújo; GRINOVER, Ada Pellegrini; DINAMARCO, Cândido Rangel. Teoria geral do processo. $30^{\mathrm{a}}$ ed. refundida. São Paulo: Malheiros Editores, 2014.

DIAS, Patrícia Mendanha. O ônus da prova no processo constitucional sob a égide do Estado Democrático de Direito. Revista Eletrônica de Direito Processual - REDP. Rio de Janeiro. Ano 10. Volume 17. Número 2. Julho a Dezembro de 2016. Periódico Semestral da Pós-Graduação Stricto Sensu em Direito Processual da UERJ. ISSN 1982-7636, p. 515-530.

DINAMARCO, Cândido Rangel. Instituições de Direito processual civil. V. III. $5^{\text {a }}$ ed. São Paulo: Malheiros, 2005.

DORI, Caroline Lovison; CAMBI, Eduardo. Distribuição dinâmica do ônus da prova (exegese do art. 373, §1 $\left.{ }^{\circ}, \mathbf{C P C} / 2015\right)$. Revista Eletrônica de Direito Processual - REDP. Rio de Janeiro, ano 12, vol. 19, n. 2, maio/ago. 2018.Periódico Quadrimestral da Pós-Graduação Stricto Sensu em Direito Processual da UERJ. ISSN 1982-7636, p. 48-66.

FREITAS, Sérgio Henriques Zandona; CAMPOS, Felipe de Almeida. O instituto jurídico da prova no direito processual brasileiro e sua (re)construção histórica. Argumenta Journal Law. Jacarezinho/PR, Brasil, n. 25, p. 301-326, jul./dez. 2016.

MITIDIERO, Daniel. Processo justo, colaboração e ônus da prova. Revista TST, vol. 78, n. 1, p. 67-77. Brasília, jan./mar. 2012.

ORDEM DOS ADVOGADOS DO BRASIL DO RIO GRANDE DO SUL. Novo Código de Processo Civil anotado. Coordenação-Geral: Elaine Harzheim Macedo e Carolina Moraes Migliavacca. Porto Alegre: OAB/RS, 2015.

PADILHA, Letícia Marques. O DIREITO À PROVA COMO UM DIREITO FUNDAMENTAL: sua aplicabilidade no âmbito processual civil e trabalhista. 2016. Disponível em: <https://www.paginasdedireito.com.br/index.php/artigos/332-artigos-jun2016/7634-o-direito-a-prova-como-um-direito-fundamental-sua-aplicabilidade-no-ambitoprocessual-civil-e-trabalhista>. Acesso em: 10 set. 2020.

RAMOS, Rodrigo. Apontamentos sobre o ônus da prova no direito processual civil brasileiro. 2015. Disponível em:

$<$ http://www.conteudojuridico.com.br/consulta/Artigos/44789/apontamentos-sobre-o-onusda-prova-no-direito-processual-civil-brasileiro>. Acesso em: 10 set. 2020. 
REICHELT, Luis Alberto; PORTO, Guilherme Athayde. Efetividade da tutela jurisdicional e o direito fundamental à prova no novo CPC.Revista Eletrônica de Direito Processual REDP. Rio de Janeiro, ano 11, vol. 18, n. 1, jan./abr. 2017. Periódico Quadrimestral da PósGraduação Stricto Sensu em Direito Processual da UERJ. ISSN 1982-7636, p. 302-324.

RODRIGUES, Marco Antonio dos Santos. A efetividade do processo e a distribuição do ônus da prova. Revista Eletrônica de Direito Processual - REDP. Rio de Janeiro, vol. 12, n. 12, 2013. Periódico da Pós-Graduação Stricto Sensu em Direito Processual da UERJ. ISSN 1982-7636, p. 545-561.

SARLET, Ingo Wolfgang. Notas introdutórias ao sistema constitucional de direitos e deveres fundamentais. In: José Joaquim Gomes Canotilho; Gilmar Ferreira Mendes; Ingo Wolfgang Sarlet; Lenio Luiz Streck, Léo Ferreira Leoncy. (Org.). Comentários à

Constituição do Brasil.1 ${ }^{a}$ ed.São Paulo/SP: Editora Saraiva, 2013, v. 01, p. 389-452.

SILVA, Anna Isis Teran; NEVES, Isabela Dias. Processo Civil Democrático: ativismo judicial frente às provas. Revista de Informação Legislativa: RIL, v. 54, n. 215, p. 97-115, jul./set. 2017. Disponível em:

<http://www12.senado.leg.br/ril/edicoes/54/215/ril_v54_n215_p97>. Acesso em 10 set. 2020.

TALAMINI, Eduardo. Ônus da prova. 2016. Disponível em:

<https://www.migalhas.com.br/depeso/235364/onus-da-prova>. Acesso em: 10 set. 2020.

TARTUCE, Flávio. Impactos do novo CPC no Direito Civil. Rio de Janeiro: Forense; São Paulo: Método, 2015. 